\title{
EVALUATION OF SEVERAL WHEAT CULTIVARS IN RESPOND TO DIFFERENT TYPES OF FERTILIZERS INCLUDING BIO-FERTILIZER UNDER RAINFED CONDITIONS
}
Fathi A. O. $^{.1}$
D. Sh. Tahir ${ }^{1}$
P. How ${ }^{2}$
Assist. Prof.
Lecturer
Researcher

${ }^{1}$ College of Agricultural Engineering Sciences, University of Duhok

${ }^{2}$ Joint Development Associates International (JDA)

E-mail: fathiemenky@uod.ac

\section{ABSTRACT}

The research was conducted during 2018-2019 growing season to study the growth and yield of various wheat cultivars under various methods of fertilizers application including biofertilizer under rainfed conditions of two different isohyets conditions. Randomized complete block design was applied with four replications. Potential grain yield is highly affected by the number of reproductive tillers; differences in final grain yield were highly and positively correlated to the number of tillers $(r=0.54 * *)$ and above ground biomass $(r=0.68 * *)$. The grain yield was about three times higher in Rikava location (3.19/1.01 t.ha $\left.{ }^{-1}\right)$. Both of Cihan and Adana99 wheat significantly produced higher grain yield $\left(2.44\right.$ and 2.43 t.ha $^{-1}$ respectively) followed by Tammoze and Italy, the Criso durum wheat was the inferior with only 1.65 t.ha $^{-1}$ grain yield. DAP fertilizer $\left(2.58 \mathrm{t}^{-h^{-1}}\right)$ was the best fertilizer treatment followed by YARA and BIO and all treatments were significantly higher than the check unit which produced only 1.7 t.ha $^{-1}$. The interaction of Adana99 with DAP (2.79 t.ha $\left.{ }^{-1}\right)$ and Cihan with DAP (2.71 t.ha ${ }^{-1}$ ) recorded highest grain yield; these two cultivars with BIO fertilizer produced significant grain yield and each gave $\left(2.5\right.$ t.ha $\left.^{-1}\right)$. Financial analysis revealed the superiority of both Anana99 and Cihan cultivars with DAP fertilizer followed by BIO fertilizer as they contributed positively with the highest final revenue.

Keywords: wheat growth, grain yield, financial analysis, rikava, dogmata, isohyets .

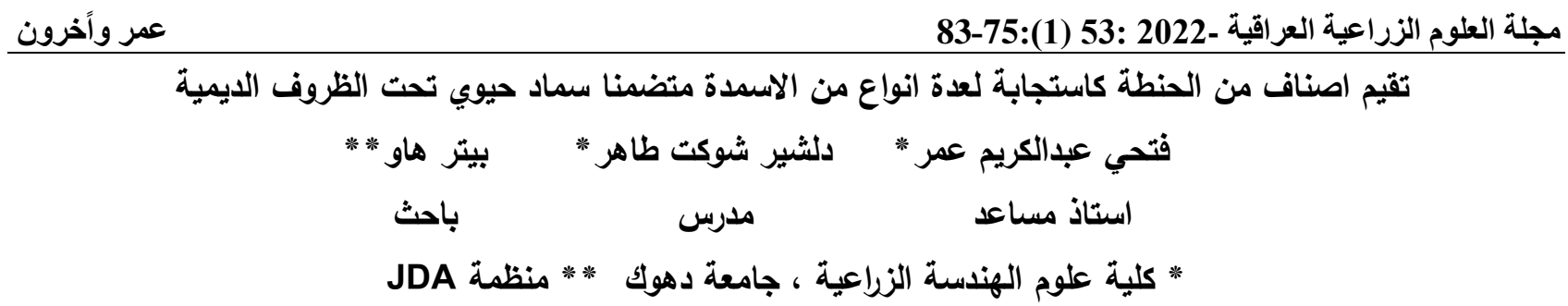

المستخلص

نفذت الاراسة في الموسم الزراعي 2019/2018 بهاف دراسة نمو وحاصل عدة اصناف من الحنطة متأثرا باستعمال طرائق

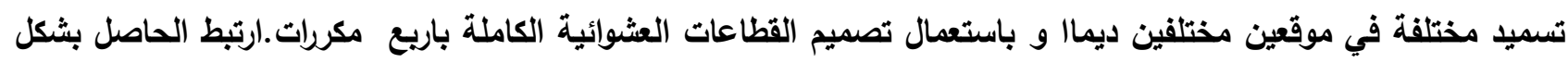
عالي بكل من عدد الاشطاء(* الاصناف جيهان وادنة99 ثم تلاهما الصنفان تموز والايطالي. جميع معاملات التسميد تفوقت بالمقارنة مع معاملة المقارنة وقد اعطت سماد الـ DAP اعلى حاصل (2.58 طن/هـ). تداخل الصنفان ادنة99 (2.79 طن/هـ) وجيهان معنويا مع طريقة التسميد بـ DAP (2.71 طن/هـ) على التداخلات الاخرى. التحليل المالي اظهرت افضلية كل من الاصناف ادنة 99 وجيهان مع السماد DAP ثم مع السماد الحيوي حيث اعطت اعلى عائد بالمقارنة مع المعاملات الاخرى. الكلمات المفتاحية: النمو، الحاصل، التحليل المالي، ركافا، دوغاتا, التسميا 


\section{INTRODUCTION}

Wheat crop consider the most world food security contributor as it has direct influence on reducing the gap between population growths and insuring daily food which source the calories for more than $35 \%$ of the world's population (8 and14). Mustafa and Jbara (11) reported that despite the efforts to increase the production of wheat grain crops, the total production is still insufficient to meet the growing consumption needs. Wheat is the dominant cultivated crop in Kurdistan region and Iraq, depending mainly on the annual rainfall starting from the mid of November to the end of May based on the environment conditions. Low yield of wheat in rainfed areas of Iraq is due to the fickle of annual precipitations in amount and distribution beside bad varietal and traditional fertilizer application and other cultural practices. According to MAWR (10), the average yield per unit area in all Kurdistan region areas from 2009 to 2018 was about $855 \mathrm{~kg} \cdot \mathrm{ha}^{-1}$. Using of traditional fertilizer and especially NPK has been stated in regards of yield improving by many researches (Keram (7); Salimpour (16); Stapper and Harris (17) and Zou (18). On the other hand, Harfe (5) recorded significant differences among wheat cultivars in relation to different nitrogen and phosphorus fertilizer regimes. Similarly, Belete (2) reported significant variation in wheat grain yield due to different fertilizer application. Wheat cultivars respond variously to the types of applied fertilizers. Deepa (4) recorded significant differences in spike and grain traits when bio-fertilizers applied. The yield of wheat can be improved by introducing of new cultivars and improving cultural practices especially fertilization and particularly those which are not harmful for the environment such bio fertilizers. Based on the previous review, some wheat cultivars including new introduced along with local cultivars and some new fertilizers in comparison to traditional and local cultivars were suggested in this study to investigate their performance under different rainfed conditions.

\section{MATERIALS AND METHODS}

This study was conducted during the growing seasons 2018/19 at two locations, Rikava village; Sharya districts $15 \mathrm{~km}$ north of Duhok city and Doghata village; Telkaif district; 45 $\mathrm{km}$ north of Duhok city and belong to Nenava Governorate administrative of Iraq to investigate the growth and yield of five different wheat cultivars (Triticum aestivum L.: Adana99 origin Turkey, Cihan origin Turkey; Tammoz local and T. durum L.; Triticum durum L.: Criso local; Italy IRIDE origin Italy ) under various fertilizers application including bio-fertilizer (Biofertilizer; Corabac G; Turkey granules $=20$ kg.ha ${ }^{-1}$ Corax-Bioner Zrt. Ze Rubar Com. Bodabist, Hungary), YaraMila complex; high potash fertilizer, $\mathrm{NPK}=(12: 11: 18)+2.7$ $\mathrm{MgO}+20 \mathrm{SO} 3+\mathrm{TE}$. Yara com., Norway, in addition to traditional DAP; Diammonum phosphate: 18:46:0 in a recommended rate of $120 \mathrm{~kg} \cdot \mathrm{ha}^{-1}$ ) comparing with the control treatment under rainfall conditions. The trials designed via Randomized complete block design and each treatment repeated four times. Due to unavailability of the meteorological stations at the both sites of the study, climate data representing both sites were collected from the station of the College of Agricultural Engineering Sciences (Figure 1). The land at both sites was plowed ten days before sowing by disc plow. Sowing dates were at $16 / 12 / 2018$, and 5/01/2019 at Rikava and Doghata locations respectively (this gap between dates of sowing was due to the continuous rainfalls). Physical and chemical analysis tests were carried out for the soil samples collected randomly from $0-40 \mathrm{~cm}$ depth. All soil properties analysis was conducted at the University of Duhok, College of Agricultural Engineering Sciences, Central Laboratory (Table 12). Plot size was $6 \mathrm{~m}^{2}$ (Six rows of $5 \mathrm{~m}$ long and $1.2 \mathrm{~m}$ between the rows ) which are matching the seeding rate of about $125 \mathrm{~kg} \cdot \mathrm{ha}^{-1}$ based on germination and weight of 1000 grains (seeds for each line were separated , $12.5 \mathrm{~g}$ to control the sowing process accurately). Distance between units was $0.5 \mathrm{~m}$ and $1 \mathrm{~m}$ between replications. Weeding was conducted manually when required. No effective pests attacked to be controlled. At the time of data measurements; ten guarded plants from one of the middle rows were measured and then the average per one plant was calculated. All possible growth and yield related traits were measured at time. The yield 
was harvested at first week of June. The data was analyzed using GenStat version 10 program (6). Least significant differences (LSD) test at 0.05 level was used for the mean comparisons. Also, financial analysis was determined based on the current costs and prices in local markets for each wheat cultivar at each particular applied fertilizer; the revenue per hectare was calculated by diminishing the total grain yield for each cultivar with the total costs.

\section{RESULTS AND DISCUSSIONS}

\section{Growth development}

Table 1 includes the analysis of variance for most of the studied traits included in this investigation, and it is clearly shows that almost all traits were significantly influenced by the studied factors with the exception of leaf area, spike density and thousand grains weight which not differed significantly by the locations. On the other hand, Table 2 shows the average values for some agronomic characters of wheat cultivars at both locations. All traits in Rikava location excluding spike density were superior and produced higher values compared to Doghata location. For plant height, both Turkish cultivars (Adana99; 88.15, $75 \mathrm{~cm}$ and Cihan; 85.91, $72.6 \mathrm{~cm}$ at both locations respectively) recorded higher values and the Italy cultivar was inferior with $67.57 \mathrm{~cm}$. On the other hand, both durum cultivars were surpassed in flag leaf area followed by Cihan bread cultivar at both locations. The difference of plant height among wheat cultivars is due to the genetic factors as this trait is controlled by genes (13, 15). Also, the plant growth such as leaf area is highly affected by environments. The same Table remarkably demonstrated that number of tillers or spike per unit area was higher for bread wheat cultivars compared to durum; Adan99 with 468.8 and 177.2 tillers per meter square was superior and both durum cultivars were inferior in this trait. Number of tillers was the limited factor in this study in which the final grain yield depended on as shown in correlation analysis and yield table (Tables 5 and 7). Both durum cultivars produced higher number of grains per spike, thousand grains weight and spike density at both locations in sequence but these traits were not correlated positively with the final grain yield (Table 7).

Table 1. Analysis of variance (ANOVA) for some of the studied traits

\begin{tabular}{|cccccccccc|}
\hline $\begin{array}{c}\text { Source of } \\
\text { variance }\end{array}$ & \multicolumn{10}{c|}{ Probability of significance } \\
\cline { 2 - 9 }$y$ & PH & LA & NT & SPD & NGP & GYSP & THGY & BIOM & GYH \\
\hline LOC. & $<.001$ & $\mathbf{0 . 7 0 0}$ & $<.001$ & $\mathbf{0 . 5 8 5}$ & $<.001$ & $<.001$ & $\mathbf{0 . 0 6 6}$ & $<.001$ & $<.001$ \\
CUL. & $<.001$ & $<.001$ & $<.001$ & $<.001$ & $<.001$ & $<.001$ & $<.001$ & $<.001$ & $<.001$ \\
FER. & $<.001$ & $<.001$ & $\mathbf{0 . 0 7 7}$ & $\mathbf{0 . 0 0 7}$ & $<.001$ & $<.001$ & $\mathbf{0 . 0 0 9}$ & $<.001$ & $<.001$ \\
LOC. $*$ CUL. & $<.001$ & $\mathbf{0 . 3 9 3}$ & $\mathbf{0 . 0 0 2}$ & $\mathbf{0 . 0 8 8}$ & $\mathbf{0 . 4 6 9}$ & $\mathbf{0 . 8 1 3}$ & $\mathbf{0 . 0 0 5}$ & $\mathbf{0 . 0 0 2}$ & $\mathbf{0 . 0 0 1}$ \\
LOC. $*$ FER. & $<.001$ & $\mathbf{0 . 0 2 9}$ & $\mathbf{0 . 0 1 5}$ & $\mathbf{0 . 1 1 8}$ & $\mathbf{0 . 0 1 3}$ & $\mathbf{0 . 0 1 5}$ & $\mathbf{0 . 0 5 9}$ & $\mathbf{0 . 0 1 0}$ & $<.001$ \\
CUL.*FER. & $<.001$ & $\mathbf{0 . 0 3 1}$ & $<.001$ & $<.001$ & $<.001$ & $<.001$ & $<.001$ & $<.001$ & $<.001$ \\
LOC. FUL. $^{*}$ FER. & $\mathbf{0 . 0 0 6}$ & $<.001$ & $<.001$ & $<.001$ & $<.001$ & $<.001$ & $<.001$ & $\mathbf{0 . 0 0 1}$ & $<.001$ \\
\hline
\end{tabular}

* LOC; locations, CUL.; wheat cultivars, FER.; fertilizers, PH; plant height (cm), LA; leaf area $\left(\mathrm{cm}^{2}\right)$, NT; number of tillers per $\mathrm{m}^{2}$, NGS; number of grains per spike, GYSP; grain yield per spike (g), THGW; thousand grains weight (g), SPD, spike density (No. spikelets per $10 \mathrm{~cm}$ spike length)

Table 2. Average values for some agronomic characters of wheat cultivars at both locations

\begin{tabular}{|c|c|c|c|c|c|c|c|c|c|c|c|c|}
\hline \multirow{3}{*}{$\begin{array}{c}\text { Wheat } \\
\text { Cultivars }\end{array}$} & \multicolumn{12}{|c|}{ Locations } \\
\hline & \multicolumn{6}{|c|}{ Rikava } & \multicolumn{6}{|c|}{ Doghata } \\
\hline & PH & LA & NT & NGSP & THGW & SPD & PH & $\mathbf{L A}$ & NT & NGSP & THGW & SPD \\
\hline Adana99 & 88.15 & 28.11 & 468.8 & 33.3 & 28.17 & 20.9 & 75.0 & 26.95 & 177.2 & 26.6 & 29.2 & 21.4 \\
\hline Cihan & 85.91 & 35.32 & 350.6 & 34.2 & 31.18 & 21.9 & 72.6 & 34.41 & 207.2 & 28.8 & 33.6 & 20.9 \\
\hline Tammoz & 79.72 & 30.44 & 329.6 & 35.8 & 29.26 & 21.3 & 69.6 & 33.08 & 150.3 & 29.2 & 25.8 & 20.4 \\
\hline Criso & 82.06 & 44.96 & 298.7 & 43.4 & 44.08 & 25.2 & 72.1 & 45.31 & 97.2 & 36.2 & 45.6 & 25.4 \\
\hline Italy & 67.57 & 35.77 & 288.9 & 39.6 & 29.65 & 26.1 & 64.8 & 36.36 & 97.4 & 29.3 & 35.7 & 28.4 \\
\hline $\begin{array}{l}\text { Mean of } \\
\text { Locations }\end{array}$ & 80.68 & 34.92 & 347.3 & 37.3 & 32.47 & 23.1 & 70.7 & 35.22 & 145.8 & 30.1 & 34.0 & 23.3 \\
\hline LSD & 2.18 & 1.55 & 53.2 & 2.05 & 3.646 & 1.97 & 2.18 & 1.55 & 53.2 & 2.05 & 3.64 & 1.97 \\
\hline
\end{tabular}

PH; plant height, LA; leaf area, NT; number of tillers, NGSP; number of grains per spike, THGW; thousand grains weight, SPD, spike density

Table 3 demonstrates some growth characters for the wheat cultivars as affected by different fertilizer application. Adana99 (81.6) surpassed other wheat cultivars in plant height, YARA fertilizer was superior $(77.2 \mathrm{~cm})$ among others. The interaction of Adana99 and 
DAP and YARA fertilizer produced highest plants. Both durum wheats produced higher flag leaf area followed by Cihan bread wheat. As for the biomass yield per unit area, all bread wheat cultivars significantly produced higher above ground biomass compared to both durum wheats. Cihan cultivar yielded higher biomass with 10.79 t.ha $^{-1}$ and the Italy cultivar yielded lower biomass $\left(7.43\right.$ t.ha $\left.^{-1}\right)$. DAP fertilizer was superior for giving higher biomass yield (10.21 t.ha $\left.{ }^{-1}\right)$ followed in sequence by each of BIO, YARA fertilizers compared to control treatment. The interaction of Cihan cultivar at all fertilizer treatments was superior for recording highest biomass yield. Biomass contribute positively for improving the grain yield $(\mathrm{r}=0.68 * *)$ and at the same time affected by most of the growth characteristics mainly plant height and number tillers (Table7). Blum (3) stated that tall plants with a higher biomass usually use water faster and, therefore, wilt faster than dwarf plants with lower biomass if exposed to drought conditions.

Table 3. Combine analysis for some growth characters (Plant height; PH, Leaf area; LA, Biomass; BIOM) of wheat cultivars under different fertilizer application (average of both locations)

\begin{tabular}{|cccccccccccccccc|}
\hline \multirow{2}{*}{$\begin{array}{c}\text { Wheat } \\
\text { cultivars }\end{array}$} & \multicolumn{4}{c}{ PH $(\mathrm{cm})$} & \multicolumn{4}{c}{ LA $\left(\mathrm{cm}^{2}\right)$} & \multicolumn{4}{c|}{ BIOM $\left({\mathrm{t} . h a^{-1}}^{-1}\right.$} \\
\cline { 2 - 6 } & BIO & DAP & YARA & $\begin{array}{c}\text { Mean } \\
\text { CUL }\end{array}$ & CON & BIO & DAP YARA & $\begin{array}{c}\text { Mean } \\
\text { CUL }\end{array}$ & CON & BIO DAP & YARA & $\begin{array}{c}\text { Mean } \\
\text { CUL }\end{array}$ \\
\hline Adana99 & 79.9 & 80.8 & 83.6 & 82.1 & 81.6 & 33.0 & 28.22 & 23.33 & 25.57 & 27.53 & 9.99 & 9.83 & 10.67 & 9.93 & 10.11 \\
Cihan & 77.5 & 78.1 & 80.1 & 80.4 & 79.0 & 40.8 & 33.20 & 33.85 & 31.53 & 34.86 & 10.97 & 11.28 & 10.96 & 9.96 & 10.79 \\
Tammoz & 70.4 & 77.4 & 76.0 & 74.9 & 74.7 & 35.1 & 31.86 & 29.81 & 30.32 & 31.76 & 6.13 & 8.84 & 9.82 & 8.94 & 8.43 \\
Criso & 77.4 & 77.1 & 75.8 & 78.2 & 77.1 & 49.1 & 41.85 & 45.65 & 43.96 & 45.14 & 8.52 & 9.16 & 10.20 & 8.89 & 9.19 \\
Italy & 60.9 & 64.6 & 69.0 & 70.3 & 66.2 & 34.3 & 37.60 & 36.88 & 35.47 & 36.07 & 6.97 & 6.68 & 9.38 & 6.71 & 7.43 \\
$\begin{array}{c}\text { Mean of } \\
\text { fertilizers }\end{array}$ & 73.2 & 75.6 & 76.9 & 77.2 & & 38.5 & 34.55 & 33.91 & 33.37 & & 8.52 & 9.16 & 10.21 & 8.89 & \\
\hline
\end{tabular}

LSD values for PH: CUL= 1.54, FER= 1.380, CUL*FER=3.087, $L S D$ values for $L A$ : $C U L=2.447, F E R=2.189$, CUL*FER=4.895, LSD values for BIOM: $C U L=0.607$, FER $=0.543$, CUL*FER=1.213

\section{Yield components}

The grain yield related traits are arranged in Table 4 showing their influence due to the wheat cultivars and fertilizer application. Grain yield is largely affected by environmental conditions, especially precipitation and soil fertility or applied fertilizers. Grain yield can be dissected into its main components; number of effective tillers per unit area, number of grains per spike and grain weight. Environment conditions and especially drought or temperature stresses may affect these components differently in different cultivars. The number of fertile tillers per unit area was generally highest bread and lowest in durum wheats. Adana99 produced higher number of tillers (322.9 tillers. $\mathrm{m}^{-2}$ ) followed by Cihan (278.8) while Criso durum wheat produced lower number of tillers (197.9) followed by the Italy cultivar. As for the fertilizers, no significant differences were observed due to the application of various fertilizers (Table 1). Potential grain yield is highly affected by the number of reproductive tillers (spikes) per area unit (Table 7). Reproductive tillers are affected by cultivars. Mandal (9) reported that number of spikes per area unit, seed weight and grain yield is mainly dependent on available water and genotypic water use efficiency. Regarding number of grains per spike, significant variations was observed between wheat cultivars and fertilizers as well as their interaction. Both Tammoz and Criso cultivars were superior in this trait and produced 39.3 and 38.7 grains per spike respectively while Adana99 was inferior with only 27.7 grains. As for the fertilizers, DAP and BIO fertilizers surpassed others with 37.6 and 36.2 grains per spike respectively. The interaction of Criso cultivar with both BIO (53.9) and DAP (48.8) fertilizers yielded higher number of grains per spike. As for the grains weight trait, the differences among wheat cultivars, fertilizers 
and their interactions were significant. Both durum cultivars and Cihan bread wheat surpassed in this trait with highest value for Criso (44.8 g) and both Tammoz and Adana99 were inferior. YARA fertilizer was significantly better than all other fertilizer treatments $(35.7 \mathrm{~g})$. Criso cultivar in all fertilizer treatments significantly produced higher grain weights. Number of grains per unit area and grain weight make up total grain

Table 4. Average of yield related traits (Number of tillers; NT, No. grain per spike; NGS, 1000 grain Weight; THGW) for wheat cultivars under different fertilizer application

\begin{tabular}{|c|c|c|c|c|c|c|c|c|c|c|c|c|c|c|}
\hline \multirow{2}{*}{$\begin{array}{l}\text { Wheat } \\
\text { cultivars }\end{array}$} & \multicolumn{4}{|c|}{ NT (Tillers. ${ }^{-2}$ ) } & \multicolumn{5}{|c|}{ NGS (grains.spike ${ }^{-1}$ ) } & \multicolumn{5}{|c|}{ THGW (gm) } \\
\hline & CON BIO & DAP & YARA & $\begin{array}{c}\text { Mean } \\
\text { CUL }\end{array}$ & CON & BIO & DAP & YARA & $\begin{array}{c}\text { Mean } \\
\text { CUL }\end{array}$ & CON & BIO & DAP & YARA & $\begin{array}{c}\text { Mean } \\
\text { CUL }\end{array}$ \\
\hline Adana99 & 239.5396 .3 & 338.6 & 317.6 & 322.9 & 27.4 & 34.1 & 30.7 & 27.7 & 29.9 & 28.5 & 26.7 & 26.6 & 32.8 & 28.7 \\
\hline Cihan & 334.3275 .8 & 268.8 & 236.5 & 278.8 & 33.1 & 30.2 & 32.6 & 30.1 & 31.5 & 30.9 & 31.1 & 35.1 & 32.5 & 32.4 \\
\hline Tammoz & 220.2293 .2 & 244.4 & 202.1 & 239.9 & 27.9 & 25.7 & 37.1 & 39.3 & 32.5 & 24.6 & 27.7 & 30.7 & 27.1 & 27.5 \\
\hline Criso & 239.8161 .4 & 224.2 & 166.5 & 197.9 & 17.7 & 53.9 & 48.8 & 38.7 & 39.7 & 48.9 & 42.1 & 40.6 & 47.7 & 44.8 \\
\hline Italy & 256.7137 .8 & 204.6 & 173.4 & 193.2 & 28.3 & 37.2 & 39.1 & 33.4 & 34.5 & 26.5 & 35.3 & 30.7 & 38.2 & 32.7 \\
\hline $\begin{array}{l}\text { Mean o } \\
\text { fertilize }\end{array}$ & 258.1252 .9 & 256.2 & 219.2 & & 26.8 & 36.2 & 37.6 & 33.8 & & 31.9 & 32.6 & 32.8 & 35.7 & \\
\hline
\end{tabular}

LSD values for NT: CUL=37.62, FER=33.64, CUL*FER=75.24, LSD values for NGS: $C U L=3.256, E R=2.913$, CUL*FER=6.513, LSD values for THGW: $C U L=2.578, F E R=2.306, C U L * F E R=5.157$

\section{Final grain yield}

For grain yield the analysis of variance revealed significant mean and interaction effects for all studied factors (Tables 5 and 6). The grain yield was about three times higher in Rikava location (3.19/1.01 t.ha $\left.{ }^{-1}\right)$. This significant surpass of Rikava location is clearly due to the superiority of this location in the number of tillers per unit area (Table 2); However the climate conditions was almost similar at both locations in respect to rainfall (Fig. 1), this big variation in grain yield may due to the site of trials and differences in soil types as in Doghata the soil was silty loam with flat land in which rainfall water was collected in the field leading to damaging root zone and reducing the amount of oxygen for root activity compared to loamy soil in Rikava (Table 12), and also due to the variation in the sowing date were in Rikava 20 days earlier which prolonged the growth period at this location. Damaging of wheat crop at the continuous rainfall conditions especially at the early season (Feb.-Mar.) is due to the low available oxygen for roots, low photosynthesis process due to cloudy days, and leaching of yield and are highly influenced by cultivars and agronomic factors such as fertilization. In our study final grain yield has not correlated positively with bot number of weight of grains which is not in a harmony with those found by Powell (12) who demonstrated that wheat grain yield is mostly affected by size and number of seed; any stress factor affecting these two traits will lead to inferior grain yield. nutrients especially Nitrogen; and this can be recovered by fertilizer application mainly Nitrogen after weed controlling. On the other side, the soil was loamy with small slop of the land not allowed high amount of rainfall in this season to effect negatively on root zone. All bread wheat and Italy durum wheat significantly produced higher yield in Rikava while Cihan and Criso were the best in Doghata location which can be recommended for this area. All fertilizers increased the final grain yield compared to control treatment. DAP fertilizer surpassed others at both locations. The interaction of Adana99 wheat cultivar with each of DAP and BIO at Rikava was the highest, while Cihan cultivar with both DAP and BIO was the superior at Rikava location. The average grain yield at both locations for the wheat cultivars in respond to fertilizer applications is displayed in Table 6. Both of Cihan and Adana99 wheat significantly produced higher grain yield (2.44

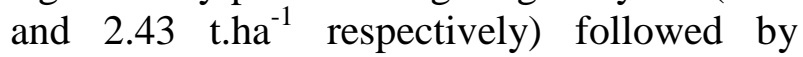
Tammoze and Italy, the Criso durum wheat was the inferior with only $1.65 \mathrm{t}^{-h^{-1}}$ grain yield. On the other hand, DAP fertilizer (2.58 
t.ha $^{-1}$ ) was the best fertilizer treatment followed by YARA and BIO and all treatment were significantly higher than the check unit which produced only $1.7 \mathrm{t}^{\mathrm{h}} \mathrm{a}^{-1}$. As for the interaction of wheat cultivars and fertilizer treatments, Adana99 with DAP (2.79 t.ha $\left.{ }^{-1}\right)$ and Cihan with DAP (2.71 t.ha $\left.{ }^{-1}\right)$ recorded higher grain yield. Also, these two cultivars with BIO fertilizer produced significant grain yield and each produced (2.5 t.ha $\left.{ }^{-1}\right)$. Differences in final grain yield were highly and positively correlated to the number of tillers $\left(\mathrm{r}=0.54^{* *}\right)$ and above ground biomass $(\mathrm{r}=0.68 * *)$ and both were higher in Rikava site and also for the winner wheat cultivars at each location (Table 7). Similarly, Banziger and Cooper (1) found also significant variation in grain yield for different what varieties in multi-location experiments. Powell (12) reported similar contributions of yield components to grain yield.

Table 5. Influence of locations, wheat cultivars, fertilizer application and their interactions on wheat final grain yield (t.ha ${ }^{-1}$ )

\begin{tabular}{|c|c|c|c|c|c|c|c|c|c|c|c|c|}
\hline \multirow[b]{2}{*}{ CUL } & \multicolumn{4}{|c|}{ Rikava LOC } & \multicolumn{8}{|c|}{ Doghata LOC } \\
\hline & $\mathrm{CON}$ & BIO & DAP & YARA & $\begin{array}{l}\text { CUL* } \\
\text { LOC }\end{array}$ & $\begin{array}{c}\text { Mean } \\
\text { CUL }\end{array}$ & $\mathrm{CON}$ & BIO & DAP & YARA & $\begin{array}{l}\text { CUL* } \\
\text { LOC }\end{array}$ & $\begin{array}{c}\text { Mean } \\
\text { CUL }\end{array}$ \\
\hline Adana99 & 3.20 & 4.23 & 4.29 & 3.91 & 3.91 & 3.91 & 0.71 & 0.79 & 1.29 & 0.98 & 0.94 & 0.94 \\
\hline Cihan & 3.19 & 3.92 & 3.98 & 3.44 & 3.63 & 3.63 & 1.00 & 1.15 & 1.45 & 1.38 & 1.24 & 1.24 \\
\hline Tammoz & 2.45 & 3.38 & 3.84 & 3.10 & 3.19 & 3.19 & 0.53 & 0.92 & 1.11 & 0.81 & 0.84 & 0.84 \\
\hline Criso & 1.51 & 1.24 & 3.29 & 2.40 & 2.11 & 2.11 & 0.84 & 0.68 & 1.89 & 1.36 & 1.19 & 1.19 \\
\hline Italy & 2.77 & 2.93 & 3.86 & 2.87 & 3.11 & 3.11 & 0.80 & 0.86 & 0.86 & 0.84 & 0.84 & 0.84 \\
\hline LOC*FER & 2.62 & 3.14 & 3.85 & 3.14 & LOC & FER & 0.78 & 0.88 & 1.32 & 1.08 & & \\
\hline LOC Mean & \multicolumn{4}{|c|}{3.19} & \multicolumn{8}{|c|}{1.01} \\
\hline
\end{tabular}

CUL; cultivar, LOC; location, FER; fertilizer, CON; control, BIO; bio fertilizer, DAP; di-ammonium Phosphate, YARA; YaraMila fertilizer

Table 6. Combine analysis of both locations for final grain yield (t.ha $\left.{ }^{-1}\right)$ of wheat cultivars under application of different fertilizers

\begin{tabular}{|c|c|c|c|c|c|}
\hline \multirow[t]{2}{*}{ Wheat cultivars } & \multicolumn{4}{|c|}{ Fertilizer Application } & \multirow[b]{2}{*}{$\begin{array}{l}\text { Mean of } \\
\text { cultivars }\end{array}$} \\
\hline & CON & BIO & DAP & YARA & \\
\hline Adana99 & 1.96 & 2.51 & 2.79 & 2.45 & 2.43 \\
\hline Cihan & 2.09 & 2.54 & 2.71 & 2.41 & 2.44 \\
\hline Tammoz & 1.49 & 2.15 & 2.47 & 1.96 & 2.02 \\
\hline Criso & 1.17 & 0.96 & 2.59 & 1.88 & 1.65 \\
\hline Italy & 1.78 & 1.90 & 2.36 & 1.86 & 1.97 \\
\hline Mean of fertilizers & 1.70 & 2.01 & 2.58 & 2.11 & \\
\hline
\end{tabular}

LSD values: LOC: 0.12, CUL: 0.19, FER: 0.17, LOC*CUL: 0.268, LOC*FER: 0.24, CUL*FER: 0.379, LOC*CUL*FER: 0.536

Table 7. Simple correlation between grain yield and yield related traits as average of both locations

\begin{tabular}{|c|c|c|c|c|c|c|c|c|}
\hline$\#$ & GYH & LA & NT & NGSP & $\mathbf{P H}$ & GYSP & SPD & THGW \\
\hline LA & $-0.26 n s$ & & & & & & & \\
\hline NT & $0.54 * *$ & $-0.20 \mathrm{~ns}$ & & & & & & \\
\hline NGSP & $-0.18 n s$ & $0.21 \mathrm{~ns}$ & $-0.59 n s$ & & & & & \\
\hline PH & $0.45 * *$ & $-0.27 n s$ & $0.40 * *$ & $-0.39 n s$ & & & & \\
\hline GYSP & $-0.02 n s$ & $0.10 \mathrm{~ns}$ & $-0.77 n s$ & $0.61 * *$ & $-0.29 n s$ & & & \\
\hline SPD & $-0.27 n s$ & $0.40 * *$ & $-0.10 n s$ & $0.16 n s$ & $-0.45 n s$ & $0.01 n s$ & & \\
\hline THGW & $0.16 \mathrm{~ns}$ & $-0.12 n s$ & $-0.45 n s$ & $-0.15 n s$ & $0.04 n s$ & $0.67 * *$ & $-0.17 n s$ & \\
\hline BIOM & $0.68 * *$ & $-0.29 \mathrm{~ns}$ & $0.38 * *$ & $-0.29 n s$ & $0.61 * *$ & $-0.13 n s$ & $-0.33 n s$ & $0.11 n s$ \\
\hline
\end{tabular}

GYH; grain yield per hectare, PH; plant height, LA; leaf area, NT; number of tillers, NGS; number of grains per spike, THGW; thousand grains weight, SPD, spike density, NGSP; number of grains per spike, GYSP; grain yield per spike, BIOM; biomass

\section{Financial analysis}

Marketing is the most problem that our farmer concern when starting sowing any crop. Absence of sufficient marketing and crop processing via industry sector caused real loss of the farmers' product which reduced their income and subsequently their demands on agriculture. On the other hand, local prices are not stable to be a benchmark for good planning. It's noted that the revenue or 
outcome for all wheat cultivars was high in DAP fertilizer treatment and followed by BIO with the exception of Criso cultivar were the revenue was in minus and that mostly due to the low yield at Doghata site as some plots at this location submerged by rainfall and caused significant reduction in final grain yield for all cultivars and Criso in particular. Adana99 and Cihan cultivars obtained higher profit and can be recommend to the farmer at these areas (Tables 8,9,10, and 11). Political stability and improving the internal security are intently needed before Iraq's agricultural sector

Table 8. Financial analysis, production costs and revenue for wheat cultivars when DAP fertilizer applied

\begin{tabular}{|c|c|c|c|c|c|c|c|}
\hline $\begin{array}{c}\text { Inputs } \\
\text { (per hectare) }\end{array}$ & $\begin{array}{c}\text { Costs per } \\
\text { hectare }(\$)\end{array}$ & $\begin{array}{l}\text { Wheat } \\
\text { variety }\end{array}$ & $\begin{array}{c}\text { Yield } \\
\text { per } \\
\text { hectare } \\
\text { (ton) }\end{array}$ & $\begin{array}{l}\text { Market } \\
\text { price per } \\
\text { ton }(\$)\end{array}$ & $\begin{array}{c}\text { Outcome } \\
\text { per } \\
\text { hectare }(\$)\end{array}$ & $\begin{array}{c}\text { Revenue } \\
\text { per } \\
\text { hectare }(\$)\end{array}$ & Remarks \\
\hline $\begin{array}{l}\text { Grains } \\
\text { Plowing }\end{array}$ & $\begin{array}{c}100 \\
48\end{array}$ & Adana99 & 2.79 & 350 & 976.5 & 544.5 & $\begin{array}{l}\text { Revenue = } \\
\text { Outcome - }\end{array}$ \\
\hline $\begin{array}{l}\text { DAP } \\
\text { fertilizer }\end{array}$ & 100 & Cihan & 2.71 & 350 & 948.5 & 516.5 & 432 \\
\hline $\begin{array}{l}\text { Weeds } \\
\text { Pest cont. }\end{array}$ & $\begin{array}{l}52 \\
64\end{array}$ & Tammoz & 2.47 & 350 & 864.5 & 432.5 & $\begin{array}{l}\text { Prices are } \\
\text { estimated }\end{array}$ \\
\hline $\begin{array}{l}\text { Harvesting } \\
\text { Other } \\
\text { Total costs }\end{array}$ & $\begin{array}{c}48 \\
20 \\
432\end{array}$ & $\begin{array}{l}\text { Criso } \\
\text { Italy }\end{array}$ & $\begin{array}{l}2.59 \\
2.36\end{array}$ & $\begin{array}{l}350 \\
350\end{array}$ & $\begin{array}{c}906.5 \\
826\end{array}$ & $\begin{array}{l}474.5 \\
394\end{array}$ & $\begin{array}{l}\text { according to } \\
\text { the season } \\
(2019)\end{array}$ \\
\hline
\end{tabular}

Table 9. Financial analysis, production costs and revenue for wheat cultivars when Bio fertilizer applied

\begin{tabular}{|c|c|c|c|c|c|c|c|}
\hline $\begin{array}{c}\text { Inputs } \\
\text { (per hectare) }\end{array}$ & $\begin{array}{c}\text { Costs per } \\
\text { donum } \\
(\$)\end{array}$ & $\begin{array}{l}\text { Wheat } \\
\text { variety }\end{array}$ & $\begin{array}{c}\text { Yield per } \\
\text { hectare } \\
\text { (ton) }\end{array}$ & $\begin{array}{l}\text { Market } \\
\text { price per } \\
\text { ton }(\$)\end{array}$ & $\begin{array}{c}\text { Outcome } \\
\text { per hectare } \\
(\$)\end{array}$ & $\begin{array}{c}\text { Revenue } \\
\text { per } \\
\text { hectare }(\$)\end{array}$ & Remarks \\
\hline $\begin{array}{l}\text { Grains, } \\
\text { Plowing }\end{array}$ & $\begin{array}{c}100 \\
48\end{array}$ & Adana99 & 2.51 & 350 & 878.5 & 418.5 & $\begin{array}{c}\text { Revenue }= \\
\text { Outcome }-\mathbf{4 6 0}\end{array}$ \\
\hline Bio fertilizer & 128 & Cihan & 2.54 & 350 & 889 & 429 & Prices are \\
\hline Weeds & 52 & Tammo & 2.15 & 350 & 752.5 & 292.5 & estimated \\
\hline Pest cont. & 64 & $\mathbf{z}$ & & & & & according to \\
\hline Harvesting & 48 & Criso & 0.96 & 350 & 336 & -124 & the season \\
\hline Other costs & 20 & Italy & 1.90 & 350 & 665 & 205 & (2019) \\
\hline Total costs & 460 & & & & & & \\
\hline
\end{tabular}

Table 10. Financial analysis, production costs and revenue for wheat cultivars when YaraMmila fertilizer applied

\begin{tabular}{|c|c|c|c|c|c|c|c|}
\hline $\begin{array}{c}\text { Inputs } \\
\text { (per hectare) }\end{array}$ & $\begin{array}{c}\text { Costs per } \\
\text { donum (\$) }\end{array}$ & $\begin{array}{l}\text { Wheat } \\
\text { variety }\end{array}$ & $\begin{array}{l}\text { Yield per } \\
\text { hectare } \\
\text { (ton) }\end{array}$ & $\begin{array}{l}\text { Market } \\
\text { price per } \\
\text { ton }(\$)\end{array}$ & $\begin{array}{c}\text { Outcome } \\
\text { per } \\
\text { hectare }(\$)\end{array}$ & $\begin{array}{c}\text { Revenue } \\
\text { per hectare } \\
(\$)\end{array}$ & Remarks \\
\hline $\begin{array}{l}\text { Grains, } \\
\text { Plowing }\end{array}$ & $\begin{array}{c}100 \\
48\end{array}$ & Adana99 & 2.45 & 350 & 857.5 & 365.5 & $\begin{array}{l}\text { Revenue = } \\
\text { Outcome - }\end{array}$ \\
\hline Yaramil & 160 & Cihan & 2.41 & 350 & 843.5 & 351.5 & 492 \\
\hline $\begin{array}{l}\text { fertilizer } \\
\text { Weeds }\end{array}$ & 52 & Tammoz & 1.96 & 350 & 668.5 & 176.5 & $\begin{array}{l}\text { Prices are } \\
\text { estimated }\end{array}$ \\
\hline $\begin{array}{l}\text { Pest cont. } \\
\text { Harvesting }\end{array}$ & $\begin{array}{l}64 \\
48\end{array}$ & Criso & 1.88 & 350 & 658 & 166 & according to \\
\hline Other costs & 20 & Italy & 1.86 & 350 & 651 & 159 & (2019) \\
\hline Total costs & 492 & & & & & & \\
\hline
\end{tabular}


Table 11. Financial analysis, production costs and revenue for wheat cultivars when No fertilizer applied (control)

\begin{tabular}{|c|c|c|c|c|c|c|c|}
\hline $\begin{array}{c}\text { Inputs } \\
\text { (per hectare) }\end{array}$ & $\begin{array}{c}\text { Costs per } \\
\text { hectare } \\
(\$)\end{array}$ & $\begin{array}{l}\text { Wheat } \\
\text { variety }\end{array}$ & $\begin{array}{c}\text { Yield per } \\
\text { hectare } \\
\text { (ton) }\end{array}$ & $\begin{array}{c}\text { Market } \\
\text { price per } \\
\text { ton }(\$)\end{array}$ & $\begin{array}{c}\text { Outcome } \\
\text { per hectare } \\
(\$)\end{array}$ & $\begin{array}{c}\text { Revenue } \\
\text { per } \\
\text { hectare }(\$)\end{array}$ & Remarks \\
\hline $\begin{array}{l}\text { Grains, } \\
\text { Plowing }\end{array}$ & $\begin{array}{c}100 \\
48\end{array}$ & Adana99 & 1.96 & 350 & 686 & 354 & $\begin{array}{l}\text { Revenue = } \\
\text { Outcome - }\end{array}$ \\
\hline Fertilizers & 0 & Cihan & 2.09 & 350 & 731.5 & 399.5 & 332 \\
\hline Weeds & 52 & Tammoz & 1.49 & 350 & 521 & 189.5 & Prices are \\
\hline Harvesting & $\begin{array}{l}04 \\
48\end{array}$ & Criso & 1.17 & 350 & 409.5 & 77.5 & $\begin{array}{l}\text { estimated } \\
\text { according }\end{array}$ \\
\hline Other costs & 20 & Italy & 1.78 & 350 & 623 & 291 & to the \\
\hline Total costs & 332 & & & & & & $\begin{array}{l}\text { season } \\
(2019)\end{array}$ \\
\hline
\end{tabular}

Table 12. Soil characteristics for the experiment sties

\begin{tabular}{|c|c|c|}
\hline \multirow{2}{*}{ Characteristics } & \multicolumn{2}{|c|}{ Location } \\
\hline & Rikava & Doghata \\
\hline pH & 8.01 & 7.56 \\
\hline $\mathbf{N}$ & 130 mg.kg ${ }^{-1}$ & 80 mg.kg ${ }^{-1}$ \\
\hline $\mathbf{P}$ & $6.13 \mathrm{mg} \cdot \mathrm{kg}^{-1}$ & 3.4 mg.kg ${ }^{-1}$ \\
\hline $\mathbf{K}$ & $4.8 \mathrm{mg} \cdot \mathrm{kg}^{-1}$ & 2.6 mg.kg ${ }^{-1}$ \\
\hline OM $(\%)^{*}$ & $1.21 \%$ & $1.01 \%$ \\
\hline Sand (\%) & 43.1 & 11.6 \\
\hline Silt (\%) & 33.4 & 72.1 \\
\hline Clay (\%) & 23.5 & 16.3 \\
\hline Soil type (texture) & Loam & Silty Loam \\
\hline
\end{tabular}

* OM, Organic material

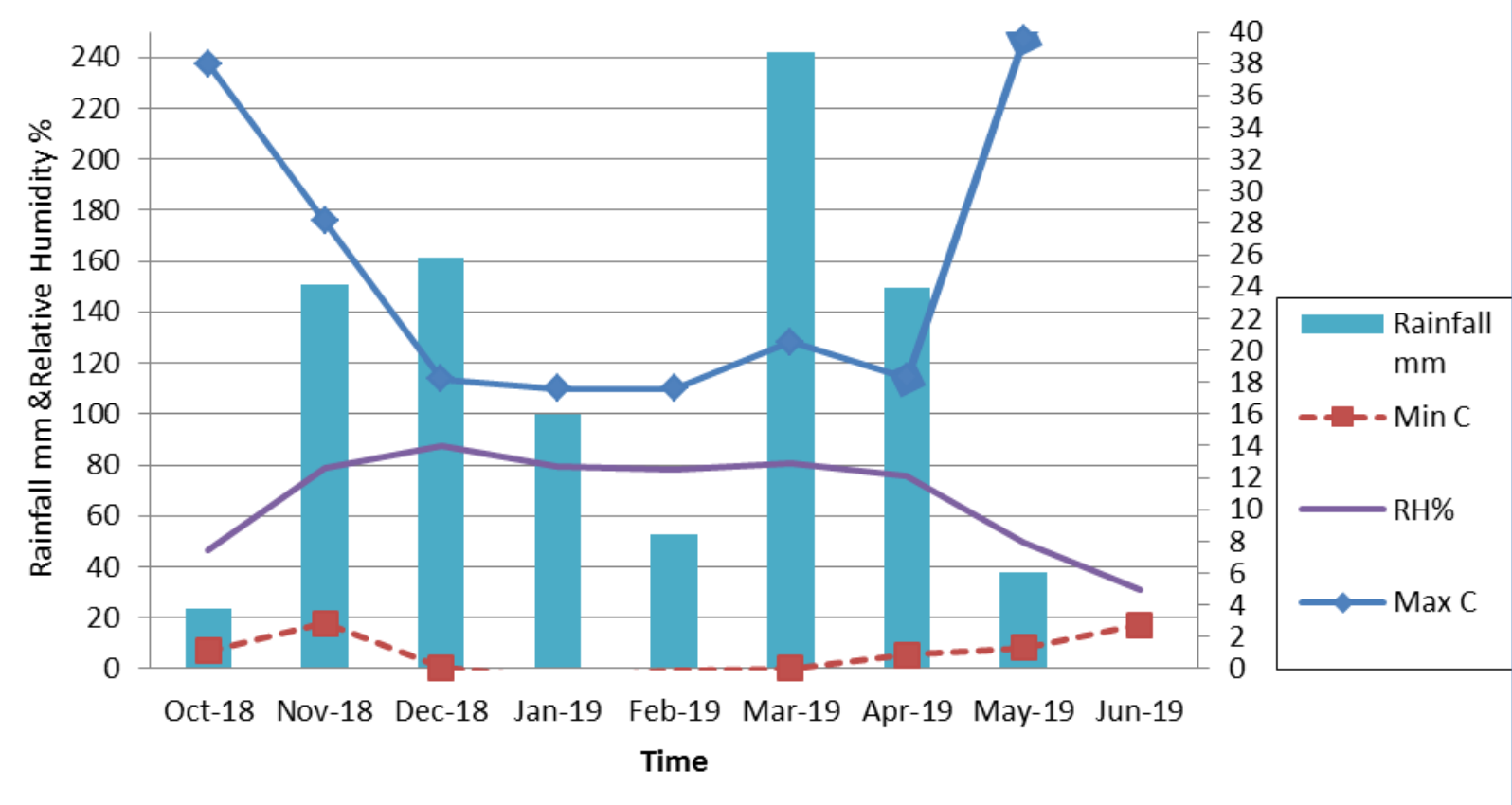

Figure 1. Meteorological data representing both sites of the experiments

\section{REFERENCES}

1. Banziger, M. and M. Cooper. 2001. Breeding for low input conditions and consequences for participatory plant breeding: examples from tropical maize and wheat. Euphytica 122: 503-519

2. Belete, F., N. Dechassa, A. Molla and T. Tamado T. 2018, Effect of nitrogen fertilizer rates on grain yield and nitrogen uptake and use efficiency of bread wheat (Triticum aestivum L.) varieties on the Vertisols of central highlands of Ethiopia. Agric \& Food Secur 7: 78. https://doi.org/10.1186/s40066018-0231-z

3. Blum A. 2011 Drought resistance - is it really a complex trait? Functional Plant Biology 38: 753-757. doi: 10.1071/FP11101 
4. Deepa, Y ,.V. Singh and S. Tyagi 2019. Effect of biofertilizer, herbicide application and nitrogen management on growth, productivity of wheat (Triticum aestivum L.). Int.J.Curr.Microbiol.App.Sci 8(4): 2712-2719.

5. Harfe M. 2017. Response of bread wheat (Triticum aestivum L.) varieties to $\mathrm{N}$ and $\mathrm{P}$ fertilizer rates in Ofla district, Southern Tigray, Ethiopia, Afr. J. Agric. Res. Vol. 12(19), 1646-1660. DOI: 10.5897/AJAR2015.10545

6. GenStat. Release 10.3DE (PC/Windows) 22 January 2011 23:16:27. 10 ${ }^{\text {th }}$ version. Gen Stat Procedure Library Release PL18.2. 2011

7. Keram, K. S.;B. L.Sharma and S. D.Sawarkar. 2012. Impact of $\mathrm{Zn}$ application on yield, quality, nutrients uptake and soil fertility in a medium deep black soil (vertisol). International Journal of Science, Environment and Technology, 1(5):563-571

8. Mahmood Z. H., A. S. Bashar and S. A. Nasir. 2018. Estimating profit and cost functions and economic and technical efficiencies of wheat production Nejaf province - Al-Abbassi Township (a case study) for season 2016. Iraqi Journal of Agricultural Sciences -1028:49(3):000-004

9. Mandal K. G., K.M. Hati . A.K., Misra K.. K., Bandyopadhyay and M.., Mohanty . 2005 Irrigation and nutrient effects on growth and water-yield relationship of wheat (Triticum aestivum L.) in Central India. Journal of Agronomy and Crop Science 191: 416-425. doi: 10.1111/j.1439037X.2005.00160.x

10. MAWR. 2019. (Ministry of Agriculture and Water Resources), Iraqi Kurdistan Region 11. Mustafa I. K. and O. K. Jbara. 2018. Forecasting the food gap and production of wheat crop in Iraq for the period (2016-2025). Iraqi Journal of Agricultural Sciences 2018:49(4):560- 568
12. Powell N., X. Ji , R. Ravash J., Edlington and,R. Dolferus . 2012. Yield stability for cereals in a changing climate. Functional Plant Biology 39: 539552. doi: 10.1071/FP12078

13. Richards, R. A. 1992. The effect of dwarfing genes in spring wheat in dry environments. I. Agronomic characteristics. Australian Journal of Agricultural Research 43: 517-27.

14. Rijib M. Z. and O.K. Jbara. 2016. Effect of variation in the measurement of space categories of wheat farms in Sulaymaniyah wheat on the level of economic efficiency and estimate the size of the efficiency achieved optimal resources. The Iraqi Journal of Agricultural Sciences - 84(1):6841-6844

15. Robertson, L. D. and G. Lowry. 2015. Seed quality and seed production. In: Robertson L. D., Guy S. O., Brown B. D. (eds.), Southern Idaho dryland winter wheat production guide, pp. 19-21. University of Idaho, Moscow, BUL 827.[http://www.cals.uidaho.edu/edcomm/pdf/ BUL/BUL0827.pdf

16. Salimpour, S.; K.Khavazi; H.Nadian; H.Besharati and M. Miransari. 2010.Enhancing phosphorous availability to canola (Brassica napus L.) using $\mathrm{P}$ solubilizincg and sulfur oxidizincg bacteria. Australian Journal of Crop Science, 4(5): 330334

17. Stapper, M. and H. C. Harris. 1989. Assessing the productivity of wheat genotypes in a Mediterranean climate, using a cropsimulation model. Field Crops Research 20: 129-152.

18. Zou, C. Q.; Y. Q. Zhang; A. Rashid; H. Ram; E. Savasli; R. Z. Arisoy and I. OrtizMonasterio. 2012. Biofortification of wheat with zinc through zinc fertilization in seven countries.Plant Soil 361:119-13. 